\begin{tabular}{|l|l|l||}
\hline \multicolumn{2}{|c|}{ PublisherInfo } \\
\hline \hline PublisherName & $:$ & BioMed Central \\
\hline \hline PublisherLocation & $:$ & London \\
\hline \hline PublisherImprintName & $:$ & BioMed Central \\
\hline \hline
\end{tabular}

\title{
Disease genes in yeast
}

\begin{tabular}{|l|l|l||}
\hline \multicolumn{2}{|c|}{ ArticleInfo } \\
\hline \hline ArticleID & $:$ & 4538 \\
\hline \hline ArticleDOI & $:$ & $10.1186 /$ gb-spotlight-20020724-01 \\
\hline \hline ArticleCitationID & $:$ & spotlight-20020724-01 \\
\hline \hline ArticleSequenceNumber & $:$ & 204 \\
\hline \hline ArticleCategory & $:$ & Research news \\
\hline ArticleFirstPage & $:$ & 1 \\
\hline \hline ArticleLastPage & $:$ & 2 \\
\hline \hline & & RegistrationDate : 2002-7-24 \\
\hline ArticleHistory & $:$ & OnlineDate \\
\hline \hline ArticleCopyright & $:$ & BioMed Central Ltd2002-7-24 \\
\hline \hline ArticleGrants & $:$ & \\
\hline \hline ArticleContext & $:$ & 130593311 \\
\hline \hline
\end{tabular}




\section{Jonathan B Weitzman}

Email: jonathanweitzman@hotmail.com

Yeast and humans look very different, but the similarities of their mitochondria make yeast a good model organism for studies of human mitochondrial diseases. In an Advanced Online Publication in Nature Genetics, Steinmetz et al. demonstrate how functional genomics in Saccharomyces cerevisiae can identify genes involved in mitochondrial respiratory functions that might be related to the hundreds of human mitochondrial diseases for which no candidate genes have been found (Nature Genetics 22 July 2002, doi:10.1038/ng929). They used the yeast deletion collection to systematically screen around 10,000 strains for survival and fitness under a range of experimental growth conditions; and they identified a large number of the genes known to be important for mitochondrial function. The screen also identified many new genes, some of which encode mitochondrial proteins while others may be important for integrating mitochondria into the cell. Steinmetz et al. found human orthologs for many of the yeast genes and show that some of these map to genomic regions implicated in mitochondrial disorders.

\section{References}

1. Yeast mitochondrial biogenesis: a model system for humans?

2. Nature Genetics, [http://www.nature.com/genetics/]

3. Quantitative phenotypic analysis of yeast deletion mutants using a highly parallel molecular barcoding strategy. 